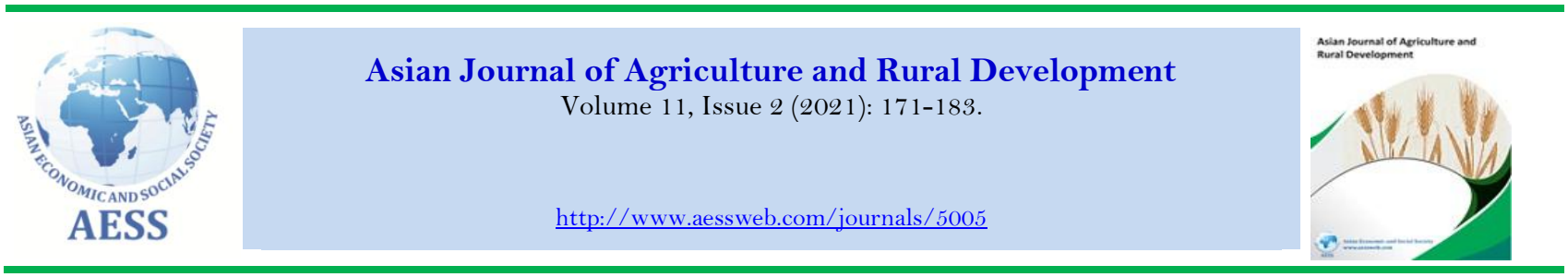

\title{
GROUNDWATER ASSESSMENT AND ITS IMPLICATION FOR IRRIGATION IN SELECTED COASTAL AREAS OF SOUTH-WESTERN NIGERIA
}

Adeyeye J. A. a Akinyemi O.D. ${ }^{\text {b }}$ Akinluyi F. O. ${ }^{\text {c }}$ Abiola M. O.d Badmus G. O

${ }^{a}$ Department of Water Resources Management and Agro-meteorology, Federal University Oye Ekiti, Ekiti State, Nigeria.

${ }^{b}$ Department of Physics, Federal University of Agriculture, Abeokuta, Ogun State, Nigeria. Department of Remote Sensing and Geoscience Information System, Federal University of Technology, Akure, Nigeria.

${ }^{d}$ Department of Agricultural Economics and Extension, Federal University Oye Ekiti, Ekiti State, Nigeria.

'Department of Mathematics and Physical Sciences, Afe Babalola University, Ado Ekiti, Ekiti State, Nigeria.

\section{هjoseph.adeveye@fuoye.edu.ng (Corresponding author)}

\section{Article History}

Received: 30 June 2020

Revised: 23 March 2021

Accepted: 28 April 2021

Published: 26 May 2021

\section{Keywords}

Aquifers

Crop

Ionic ratio

Physicochemical

Suitability

Saltwater intrusion.

\begin{abstract}
Physicochemical and ionic characteristics of groundwater aquifers have been of tremendous importance in water applications. Groundwater in selected coastal communities (Badagry, Epe, Ikorodu, and Ilaje/ese-odo) of southwestern Nigeria was assessed for domestic and irrigation suitability. One hundred and ninety-two (192) groundwater samples were obtained and analyzed for chemical composition and major ionic ratio over a period of four seasons using standard methods. Results indicated abundance of ions in the order $\mathrm{HCO}_{3}{ }^{-}>\mathrm{Cl}^{-}>\mathrm{SO}_{4}{ }^{2-}$ for anions, and $\mathrm{K}^{+}>\mathrm{Na}^{+}>\mathrm{Ca}^{2+}>\mathrm{Mg}^{2+}$ for cations. Piper's diagram revealed calcium $\left(\mathrm{Ca}^{2+}\right)$ and magnesium $\left(\mathrm{Mg}^{2+}\right)$ as the dominant cations, while sulphate and chloride were the dominant anions with a mixture of two major groundwater types: $\mathrm{Ca}-\mathrm{Cl}$ water and mixed $\mathrm{Ca}-$ $\mathrm{Mg}-\mathrm{Cl}$. The presence of $\mathrm{Ca}-\mathrm{Cl}$ facies water type suggests potential ion exchange $\left(\mathrm{Na}^{2+}\right.$ with $\left.\mathrm{Ca}^{2+}\right)$ reaction in these coastal aquifers. Cation exchangeable values $(\mathrm{CEV})$, and molar ratios of $\mathrm{Mg} / \mathrm{Ca}, \mathrm{HCO}_{3} / \mathrm{Cl}$, and $\mathrm{Na} / \mathrm{Cl}$, showed high values $(>1)$ across all locations indicating the occurrence of saline water ingression in groundwater samples, especially during the dry spell. The increasing $\mathrm{K}^{+}, \mathrm{Na}^{+}$, and $\mathrm{Cl}^{-}$characteristics of the groundwater and calculated ionic indices values indicated the influence of seawater intrusion. However, total hardness values showed that the samples were very soft in nature. Irrigation water quality suitability, as indicated by sodium adsorption ratio (SAR), permeability index (PI), and percentage sodium (PS) varied with seasons and location, showing that water will cause soil deterioration and poor crop performance if intensively used for irrigation without proper precautions.
\end{abstract}

Contribution/Originality: This study is one of few studies to have investigated groundwater quality for irrigation in a coastal environment in relation to extreme climate events and seasonal variation in south western, Nigeria. Evidence derived from analytical processes revealed short-term variations in soluble salt content that will affect irrigation suitability.

DOI: $10.18488 /$ journal.ajard.2021.112.171.183

$\operatorname{ISSN}(\mathrm{P}):$ 2304-1455/ ISSN(E): $2224-4433$

How to cite: Adeyeye J. A. --- Akinyemi D.O. --- Akinluyi F. O. --- Abiola M. O. --- Badmus G.O (2021). Groundwater Assessment and its Implication for Irrigation in Selected Coastal Areas of South-Western Nigeria. Asian Journal of Agriculture and Rural Development, 11(2), 171-183. 10.18488/journal.ajard.2021.112.171.183 (C) 2021 Asian Economic and Social Society. All rights reserved. 


\section{INTRODUCTION}

Groundwater salinity in coastal zones of the world is increasingly becoming a major challenge. While households are heavily dependent on this resource for daily living, irrigation water use is crucial to maintaining arable crop production, especially when there is inadequate rainfall or in the dry season. Groundwater contributes greatly to the economic and social activities of people in Nigeria. Though fairly ubiquitous, its characteristics vary from one place to another and extraction is frequently carried out without adequate information on hydro-chemical attributes, especially in developing countries, before use (Luo, Gao, \& Zhang, 2018). The chemistry of groundwater is principally a product of mineral composition of the aquifers through which the water flows. Spatial and temporal variation also depend on geology and chemical characteristics. More importantly, processes such as ion exchange, dissolution, precipitation, residence time, and downwater path determine the elemental characteristics of groundwater.

Manikandan, Natarajan, and Sivasamy (2011) reported the complexity of groundwater characteristics in coastal communities due to the influence of factors such as rainfall, saltwater ingression, geology, degree of groundwater exploitation, topography, and contamination rate. Excessive groundwater removal often depletes the source and higher concentrations of certain ions, which frequently results in water becoming unfit for its intended uses.

The chemical nature of groundwater has been one of the major tools used to match its suitability and usability, from time immemorial. Hakim et al. (2009) emphasized the important of the physical characteristics of water in classifying and assessing water requirement for domestic and agricultural purposes. Groundwater suitability for irrigation farming is dependent on the effect of mineral compositions in the soil and farm produce (Raihan \& Alam, 2008).

The hydro-geochemical characteristics of groundwater and potability of aquifers in a spatiotemporal context have proven to be a vital method in demystifying water challenges. It has also helped in highlighting the major geochemical processes dictating groundwater chemistry and thus groundwater categorization. Mohan, Singh, Tripathi, and Chowdhary (2000) found that $\mathrm{Na}^{2+}, \mathrm{Mg}^{2+}$, and $\mathrm{HCO}_{3}{ }^{-}$have dominated groundwater in the Naini industrial area of Uttar Pradesh, and concluded that the groundwater was unsafe for domestic purposes. In the Nigerian coastal environment, comprehensive understanding revealing chemical indicators and hydro-chemical emergence using empirical field data is sparse. Thus, this study investigated the hydro-chemistry and groundwater characteristics in selected coastal areas for the purposes of evaluation, classification of groundwater suitability for domestic use, and to help farmers in the region to better plan irrigation to boost food production throughout the year. Also, the dominant processes that control aquifer composition were also studied.

\section{MATERIAL AND METHODS}

\subsection{Study Area}

The study area under investigation is located between $15^{\circ} 51^{\prime} 14.4^{\prime \prime}$ and $6^{\circ} 42^{\prime} 36^{\prime \prime} \mathrm{N}$ and $2^{\circ} 42^{\prime} 28.8^{\prime \prime}$ and $5^{\circ} 0^{\prime} 18^{\prime \prime}$ E, covering the Badagry, Ikorodu, and Epe local government areas (LGAs) of Lagos State and Ilaje/Ese-odo LGA of Ondo State, south-western Nigeria (Figure 1). Vegetation in the area varies from mangrove and swamp to rainforest. The area has a wet (rainy) season from the end of March to October, and a dry season from November to the end of February. The wet season is associated with the south-western monsoon wind from the Atlantic Ocean, while the dry season is driven by northeast trade winds from the Sahara Desert. It is characterized by the south-westerlies, which are onshore and confined generally to azimuths of $215-266^{\circ}$ and velocities of $2-5 \mathrm{~m} / \mathrm{s}$ (Fatai, Egberongbe, Olusegun, \& Badejo, 2006). Wind speed increases to about $10 \mathrm{~m} / \mathrm{s}$, especially during heavy rainfall and thunderstorms in the wet season. Cloud cover and damp air moderate the temperature of the area, with mean monthly temperatures ranging from 24 to $32^{\circ} \mathrm{C}$ throughout the year.

\subsection{Sampling and Analysis of Groundwater Samples}

Groundwater samples were collected from shallow (hand-dug) wells and from deep holes (boreholes) whose depth varied between 3 and $80 \mathrm{~m}$ across the four locations. Forty-eight (48) groundwater samples were collected consecutively during dry season I (Dec. 2015 - Feb. 2016) and wet season I (June 2016 - August 2016), and during dry season II (December 2016 - February 2017) and wet season II (June 2017 - August 2017) across the area, making a total of 196 water samples. Before groundwater sampling, tap wells (including the boreholes) were allowed to flow for about three minutes to avoid taking water retained in the pipes as sample. Pre-conditioned plastic bottles were used for sample collection after correct labeling at the point of collection (BH1, BH2... and BH12) and being tightly corked. Non-preservative parameters (temperature, colour, pH, electrical conductivity (EC), and total dissolved solids(TDS)) were measured in-situ with a hand-held multi-parameter meter (Hannah HI9828). The 1-l plastic containers for cation analysis were acidified with $2 \mathrm{ml}$ of strong trioxonitrate $\mathrm{V}$ acid in order to homogenize and prevent absorption or adsorption of ions to the wall of the container. The sampled water were preserved in an ice cooler to keep the temperature below $20^{\circ} \mathrm{C}$, and was conveyed to the Institute of Agricultural Research and Training (IAR\&T) Laboratory, Ibadan, where samples were analyzed. These were stored in the refrigerator prior to analysis. Moreover, to reduce sampling error, measurements were replicated from both field and laboratory measurements. 


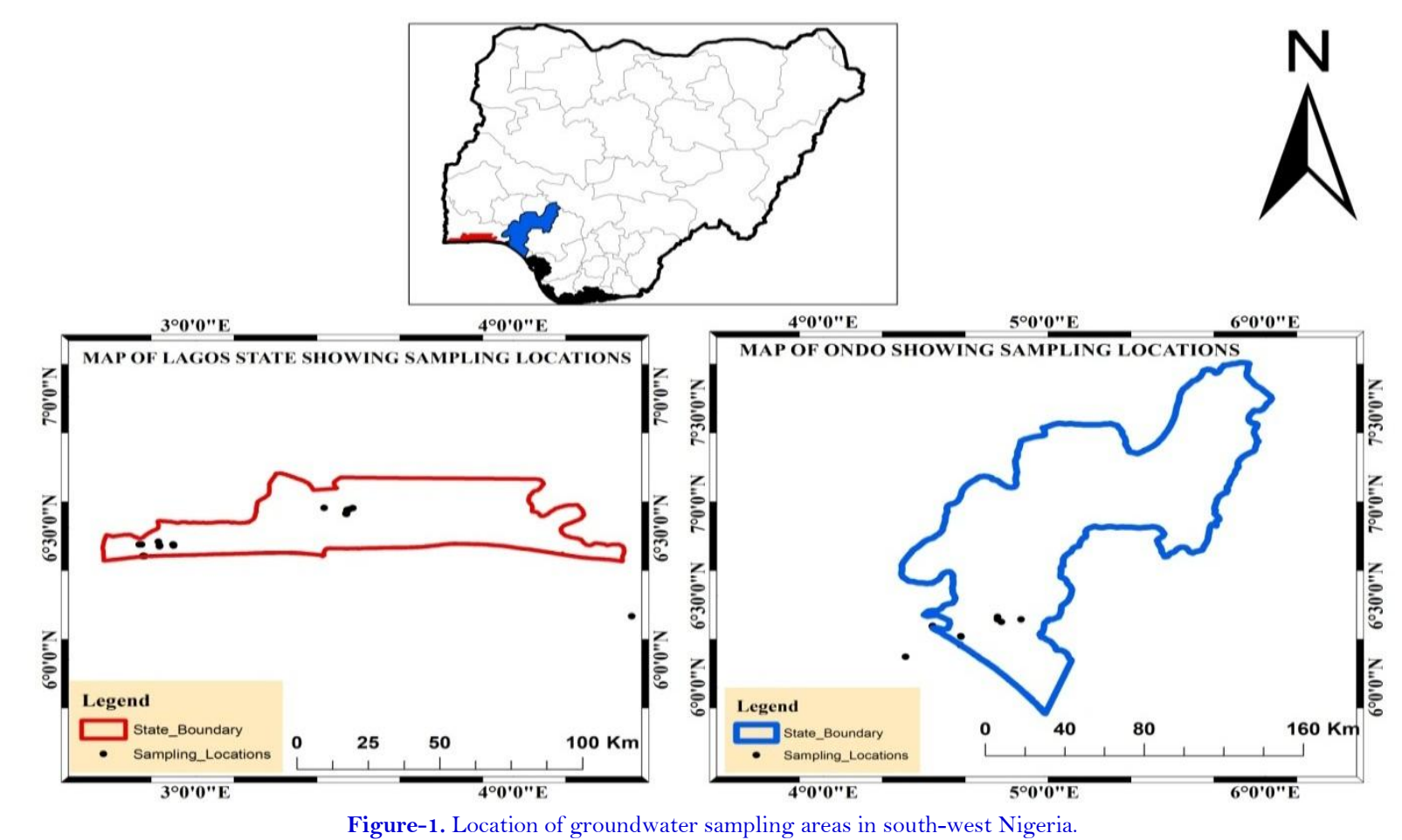

Source: Data Analysis (2017) using Arc GIS version 10.4.

Groundwater samples collected from the selected coastal areas were analyzed following standard procedures. $\mathrm{EC}, \mathrm{pH}, \mathrm{TDS}$, and temperature $\left({ }^{\circ} \mathrm{C}\right)$ were determined by a Hanna multi-parameter meter (HI-98106) USA). The titrimeteric procedure was followed to determine $\mathrm{HCO}^{-}$and $\mathrm{Cl}^{-}$. Sulphate $\left(\mathrm{SO}_{4}{ }^{2-}\right)$ was analyzed gravimetrically. $\mathrm{Na}$ and $\mathrm{K}$ were determined with the flame photometer method, while $\mathrm{Mg}$ and $\mathrm{Ca}$ were measured using an atomic absorption spectrophotometer (Bulk 210).

\subsection{Data Analysis}

Data were analyzed using descriptive analysis to decipher the average compositions of major and minor ions. Moreover, Piper diagrams were also used to describe relative ionic composition and delineate water types. Anion and cation concentrations were converted to equivalent units (meq/l), illustrated as percentages of individual totals in two Piper triangles merged into a quadrilateral polygon, which gives the groundwater type or hydro-chemical facies. Ionic ratio was also used to give the ionic proportions that helped explain prevailing processes in the hydrology of the area.

Ionic relationships were studied to assess saltwater intrusion influence and groundwater origin in the area. These include: $\mathrm{Mg} / \mathrm{Ca}, \mathrm{Cl} / \mathrm{HCO}_{3}, \mathrm{Na} / \mathrm{Cl}$ and Cationic Exchange Value (CEV), as shown in Equation 1:

$$
C E V=\frac{\mathbb{C l}^{-}\left[\mathrm{Na}^{+}+K\right.}{\mathrm{Cl}^{-}}
$$

Other irrigation water quality indices were determined (sodium absorption ratio (SAR), PI, and percentage soluble sodium:

$$
S A R=\frac{N a^{+}}{\sqrt{\left(M g^{2+}+C a^{2+}\right) / 2}}
$$

Irrigation quality of groundwater was categorized based on the PI value, as indicated by Equation 3:

$$
P I=\frac{\mathrm{Na}^{+}+\sqrt{\mathrm{HCO}}}{\mathrm{Ca}^{2+}+\mathrm{Mg}^{2+}+\mathrm{Na}^{+}} * 100
$$

Soluble sodium percentage was determined from Equation $4:$

$$
S S P=\frac{\mathrm{Na}^{+}+\mathrm{K}^{+}}{\mathrm{Mg}^{2+}+\mathrm{Ca}^{2+}+\mathrm{Na}^{+}+\mathrm{K}^{+}} * 100
$$

\section{RESULTS AND DISCUSSION}

\subsection{Physicochemical Characteristics of Groundwater Samples}

The $\mathrm{pH}$ ranged from 5.09 to 7.90 throughout the period, with mean values of 6.17 and 6.07 for the dry and wet season, respectively. pH was slightly acidic to slightly alkaline in Badagry, Epe Ikorordu LGA, and Ilaje Ese Odo LGA. This behaviour was linked to uncontrolled human activity such as fertilizer application from agricultural fields (cassava farms and coconut plantations, which are common features in the study area), sewage disposal, and incursion of brackish water into sandy groundwater strata, which results in weathering the course of underlying geology (Srinivas, Aghil, Oliver, Nair, \& Chandrasekar, 2017) and has affected the water quality, thus the pH characteristics. The groundwater samples simply behaved similarly, in being slightly acidic to alkaline across the area. Spatial and temporal variation was also affected by the rate of aquifer recharge, replenishing rate, and water rock interactions. 
The $\mathrm{pH}$ indicated good water quality for agriculture (irrigation) across the study area, since most crops will normally do well within the $\mathrm{pH}$ range 6.5-8.4 for irrigation (Bauder, Waskom, Sutherland, \& Davis, 2011).

EC values varied from 1056 to $2249 \mu \mathrm{S} / \mathrm{cm}$, with mean values of 1191.64 and $1149 \mu \mathrm{S} / \mathrm{cm}$ for dry and wet periods, respectively. EC describes water salinity hazard, which seems to be the most significant water quality guideline regarding crop performance (Johnson \& Zhang, 1990). The EC value is an estimated index of total dissolved solids in water. $\mathrm{pH}$ has also been reported as a major factor that increases dissolution processes triggering $\mathrm{EC}$ values. The higher value obtained for the wet season is attributed to both underground and surface erosion, which flushes nutrients into sandy aquifers or wells. The main effect of high EC when used for irrigation is the resultant physiological effect resulting from the inability of plants to compete with ions in the soil (Naseem, Hamza, \& Bashir, 2010). Observed across the study area was the high nutrient accumulation in aquifers, which is a peculiar feature of coastal communities and usually as a result of intensive rainfall, low land characteristics, or high runoff.

TDS varied between 513.30 and $1439.30 \mathrm{mg} / \mathrm{l}$, with mean values of 634.40 and $762.65 \mathrm{mg} / \mathrm{l}$ for dry and wet spells, respectively. Categorization of groundwater samples (Davis and De west, 1996) showed that all the groundwater samples fall outside the desirable category $(<500 \mathrm{mg} / \mathrm{l})$ for potable water, $100 \%$ tolerable for drinking $(500-1000 \mathrm{mg} / \mathrm{l})$, and appropriate for irrigation agriculture.

Alkalinity primarily comprised carbonate and bicarbonate and as a stabilizer of $\mathrm{pH}$. Values ranged between 43.15 and $2147 \mathrm{mg} / \mathrm{l}$, with mean values of 281.46 and $347.04 \mathrm{mg} / \mathrm{l}$ for the dry and wet seasons, respectively, across the study area. Although the samples were collected along the coast, alkalinity was high, showing freshwater characteristics due to $\mathrm{CO}_{3}$ and $\mathrm{HCO}_{3}$ levels. Elevated concentrations of carbonate and bicarbonate indicated the prevalence of mineral dissolution in these aquifers across the study area. The mean values were above the $100 \mathrm{mg} / \mathrm{l}$ recommended for drinking water (World Health Organization (WHO), 2011). The mean values of 281.46 and 347.04 $\mathrm{mg} / \mathrm{l}$ for bicarbonate $\left(\mathrm{HCO}_{3}\right)$ during the dry and wet season respectively, are much higher than the maximum tolerable limit of $244 \mathrm{mg} / \mathrm{l}$ for crops (SAI, 2010). High bicarbonate ion concentrations of $\mathrm{Mg}$ or Ca would normally result in carbonate in the soil solution concentrate during the dry season.

Chloride ions varied from 51.5 and $995.5 \mathrm{mg} / \mathrm{l}$, with mean values of 224.21 and $270.06 \mathrm{mg} / 1$ for the dry and wet season, respectively. It was observed that $35.42 \%$ of the groundwater samples were characterized by chloride concentration $>250 \mathrm{mg} / \mathrm{l}$, the recommended limit for drinking (World Health Organization (WHO), 2011) across the study location. High chloride concentrations were noted at Badagry, Epe, Ikorodu, and Ilaje Ese Odo, indicating ingress of saltwater into freshwater aquifers in the region. A high concentration of chloride has also been linked to domestic sewage pollution and washing of saline residues into the soil (Raju, Shukla, \& Ram, 2011) in coastal environments. Chloride concentrations $>359 \mathrm{mg} / \mathrm{l}$ have been reported to cause severe problem in crops when administered for irrigation (Hopkin, Horneck, Stevens, Ellswort, \& Sullivan, 2007). On average, chloride concentrations for both seasons were below this value, which makes the water suitable for irrigation although the concentration of chloride in certain wells was about $1000 \mathrm{mg} / 1$, and thus there is a need for close monitoring and continuous assessment of individual wells to ensure that concentrations are within the acceptable limit for irrigation.

Sulphate concentration varied from 2.75 to $13.50 \mathrm{mg} / \mathrm{l}$, with average values of 7.37 and $7.60 \mathrm{mg} / \mathrm{l}$ for dry and wet spells, respectively. Ikorodu recorded the maximum during the wet season, while Badagry had the minimum during the dry season. Excessive accumulation of sulphate in groundwater is associated with processes such as precipitation, solution, reduction, and concentration, because it permeates via rocks such as anhydrite and gypsum. The average concentration was below the permissible limit of $100 \mathrm{mg} / 1$ stipulated (World Health Organization (WHO), 2011) for domestic applications. Aptness for irrigation with respect to sulphate revealed that the groundwater samples were within the acceptable limit of $1000 \mathrm{mg} / 1$ for optimal plant performance. Concentrations above this limit are harmful for plants (Sagnak, 2010).

The spatial and temporary distribution of cations in the area showed that sodium $\left(\mathrm{Na}^{+}\right)$ions ranged between 9.78 and $32.11 \mathrm{mg} / \mathrm{l}$, with mean values of 15.55 and $24.94 \mathrm{mg} / \mathrm{l}$ for dry and wet spells, respectively. Concentration of sodium was $<200 \mathrm{mg} / \mathrm{l}$, as recommended (World Health Organization (WHO), 2011), which categorized the water as potable although concentrations were sometimes well above $20 \mathrm{mg} / 1$, the recommended dietary intake for individuals with restricted sodium intake. Groundwater with a high sodium concentration is not fit for agriculture (soil alkalization). Soils are sometimes enriched with sodium from irrigated water, which often results in loss of soil structure, impermeability, imbalance in soil nutrients, and poor plant performance. Evidence shows that sodium was second to potassium in concentration order across the study area, and with respect to the seasons. The area generally showed higher sodium concentrations in all water samples, especially in the wet season in Badagry and Epe, followed by calcium and magnesium ions. Potassium varied between 24.42 and $45.44 \mathrm{mg} / \mathrm{l}$, with an average of 34.80 (dry) and $38.60 \mathrm{mg} / \mathrm{l}$ (wet). The concentration of potassium remained high $(>12 \mathrm{mg} / \mathrm{l})$ across the study areas compared with $\mathrm{Na}^{+}, \mathrm{Mg}^{2+}$ and $\mathrm{Ca}^{2+}$, due to saline water intrusion (Kumar, Bharani, Magesh, Godson, \& Chandrasekar, 2014). Potassium concentration was consistently higher during the dry season across Badagry, Epe, Ikorodu, and Ilaje/eseodo in Ondo State than in the wet season, due to seawater intrusion. Over drafting could also result in ion imbalance in groundwater composition, particularly during the dry season when the rate of groundwater recharge is low. Potassium concentration $>10 \mathrm{mg} / \mathrm{l}$ in irrigation water are detrimental to good plant growth (SAI (Spectrum Analytic Inc.), 2010). Groundwater concentration of potassium across the study area appeared high, irrespective of location and season. This calls for caution in groundwater usage for agricultural purposes in the area in regard to optimum crop production.

Calcium varied between 0.56 and $2.75 \mathrm{mg} / 1$, with mean values of 2.02 and $1.48 \mathrm{mg} / 1$ for the dry and wet period, respectively. Ilaje recorded the maximum $(2.75 \mathrm{mg} / \mathrm{l})$ during the dry season, while Badagry, Epe, and Ikorodu recorded the minimum $(0.56 \mathrm{mg} / \mathrm{l})$. The observed estimate of calcium ions across the area was within the acceptable 
tolerance level in relation to water irrigation quality. The concentration range of $121-150 \mathrm{mg} / \mathrm{l}$ is high, and $>150$ $\mathrm{mg} / \mathrm{l}$ may be very high for optimum crop performance (SAI (Spectrum Analytic Inc.), 2010). Magnesium concentration varied between 0.09 and $5.55 \mathrm{mg} / \mathrm{l}$, with mean values of 1.61 and and $0.48 \mathrm{mg} / \mathrm{l}$ for the dry and wet seasons, respectively. Concentrations of calcium and magnesium were low probably due to low levels of rock water (dolomite, limestone, and gypsum among others) interaction in the region, which naturally contribute to the concentrations. The observed elevated concentration of sodium in groundwater samples across the location relative to calcium and magnesium can be attributed to reverse cationic exchange (Srinivas et al., 2017). The spatial and temporary distribution of cations is illustrated in Figures 2-5.

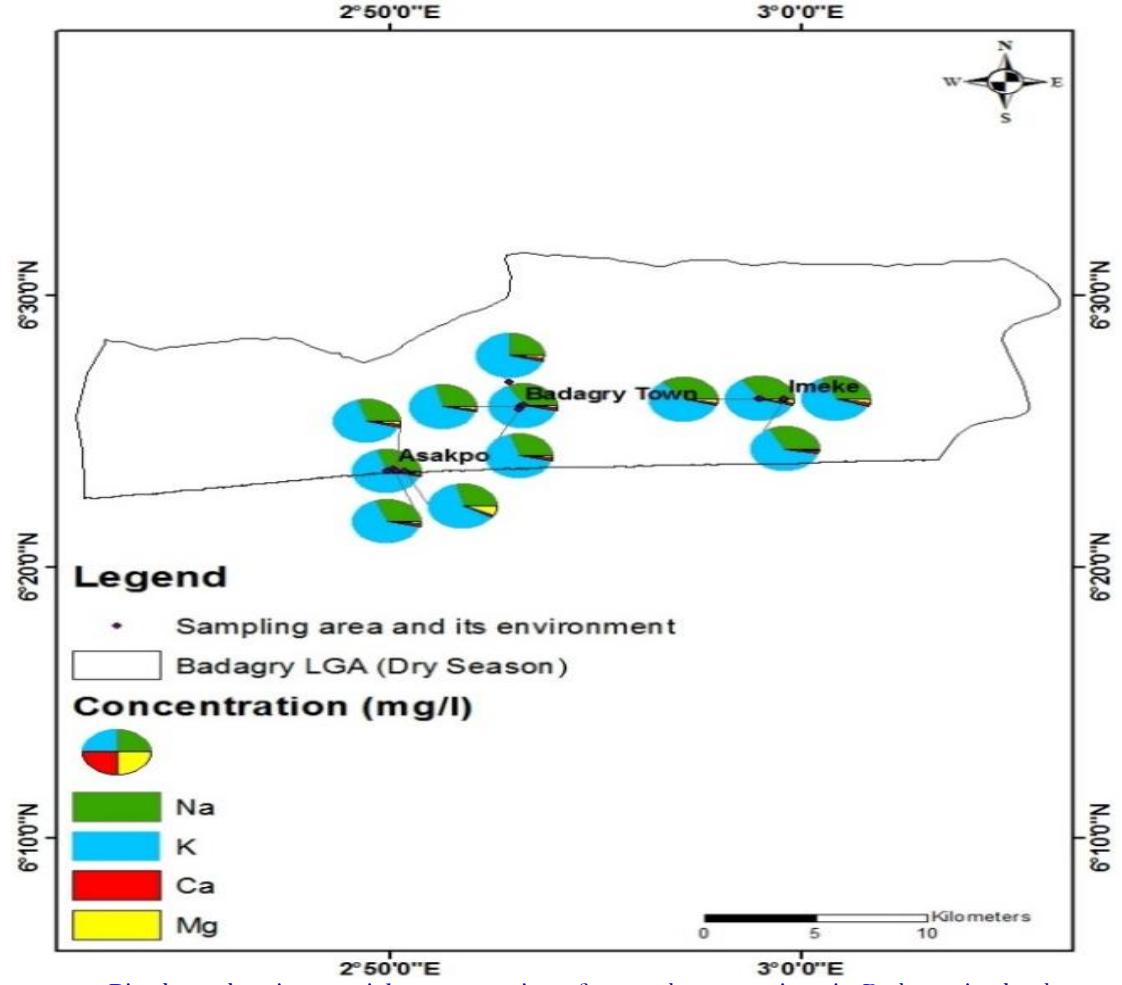

Figure-2a. Pie chart showing spatial concentration of groundwater cations in Badagry in the dry season Source: Data Analysis (2015 - 2017) using Arc GIS version 10.4

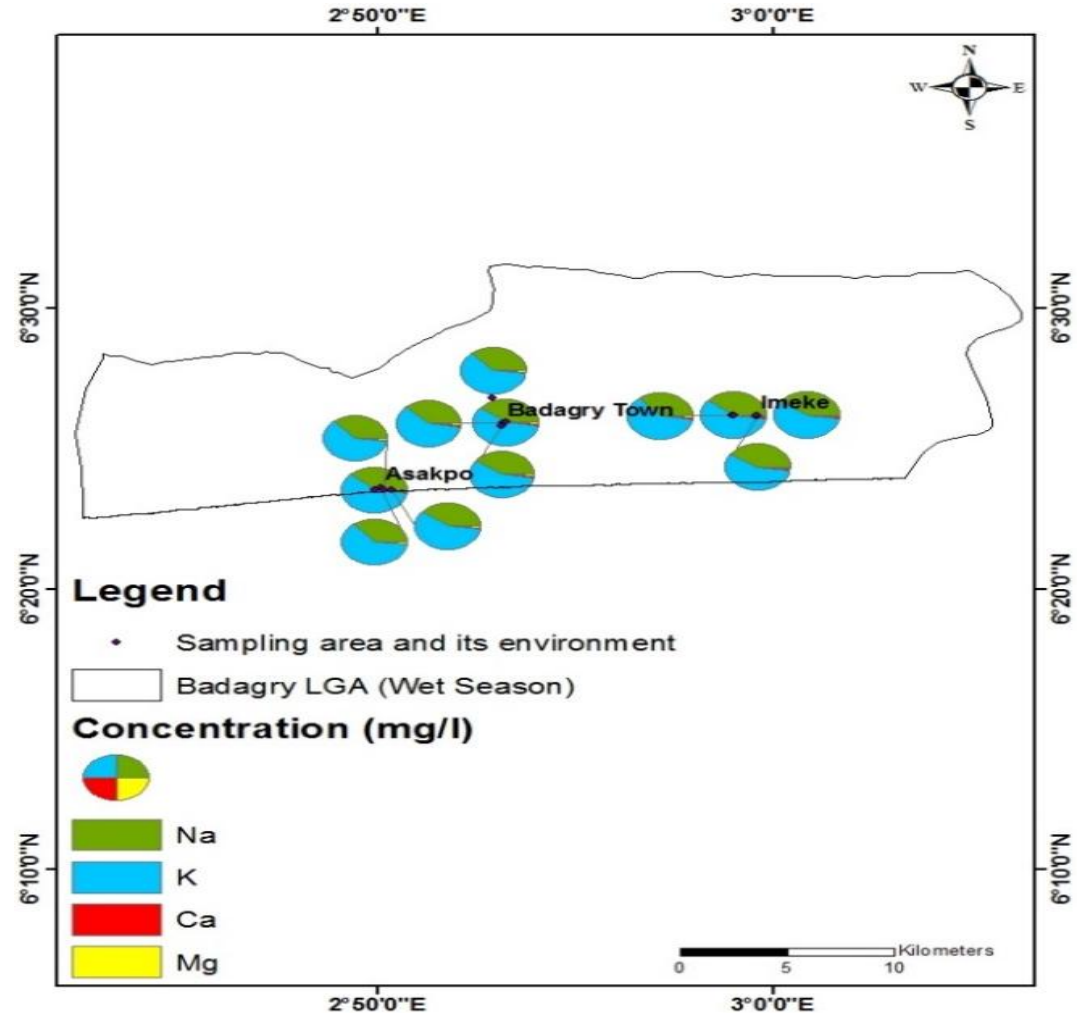

Figure-2b. Pie chart showing spatial distribution of cations in Badagry in the wet season. Source: Data Analysis (2015 -2017) using Arc GIS version 10.4. 


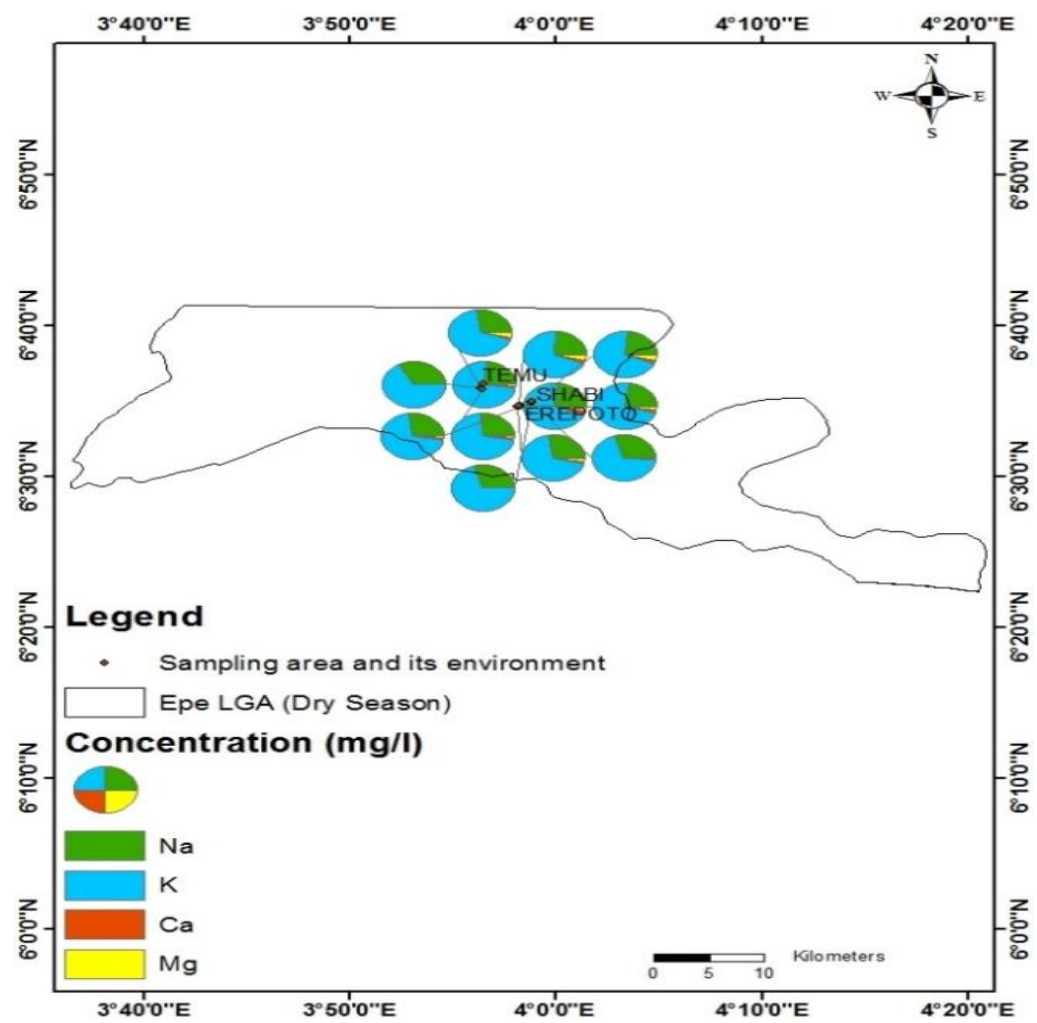

Figure-3a. Pie chart showing spatial distribution of cations in Epe in the dry season. Source: Data Analysis $(2015-2017)$ using Arc GIS version 10.4.

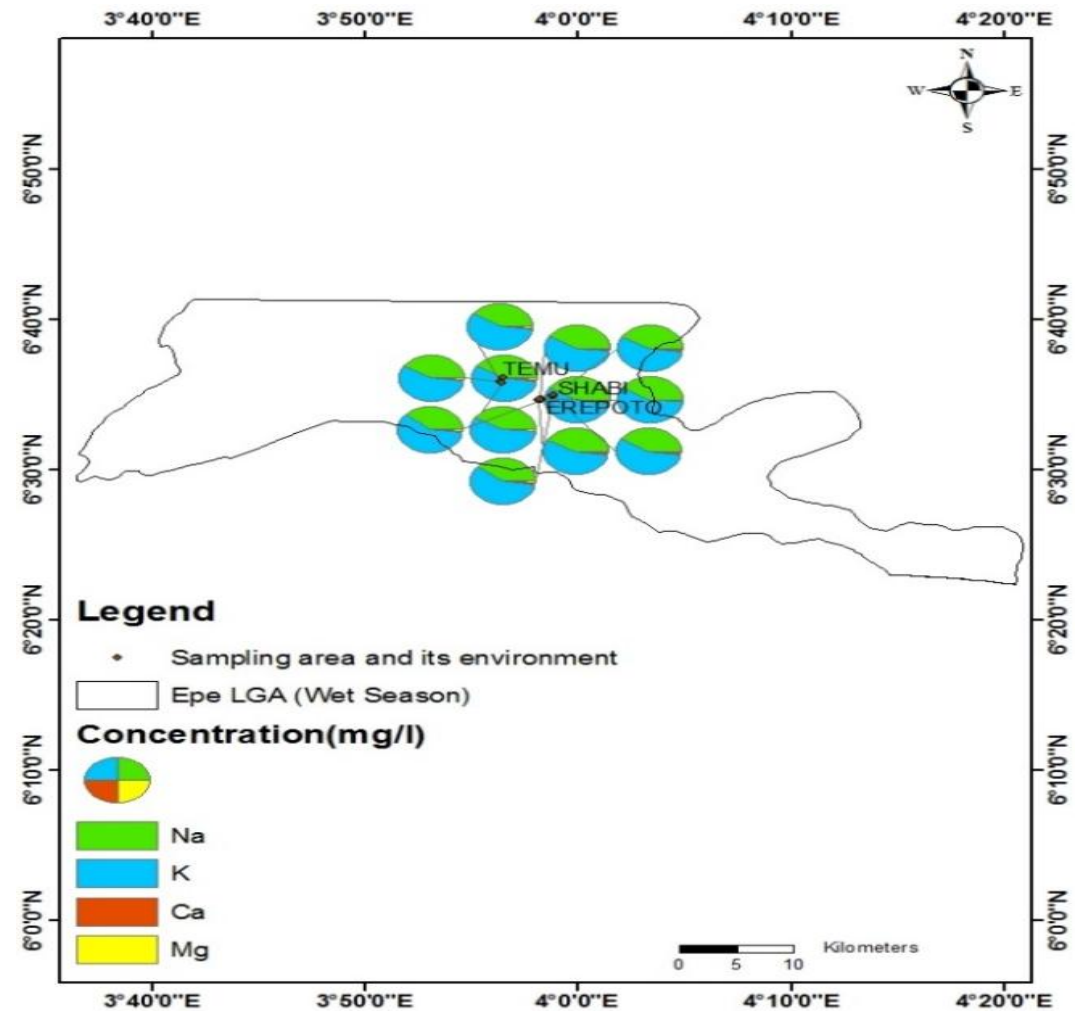

Figure-3b. Pie chart showing spatial distribution of cations in Epe in the wet season. Source: Data Analysis (2015 -2017) using Arc GIS version 10.4 


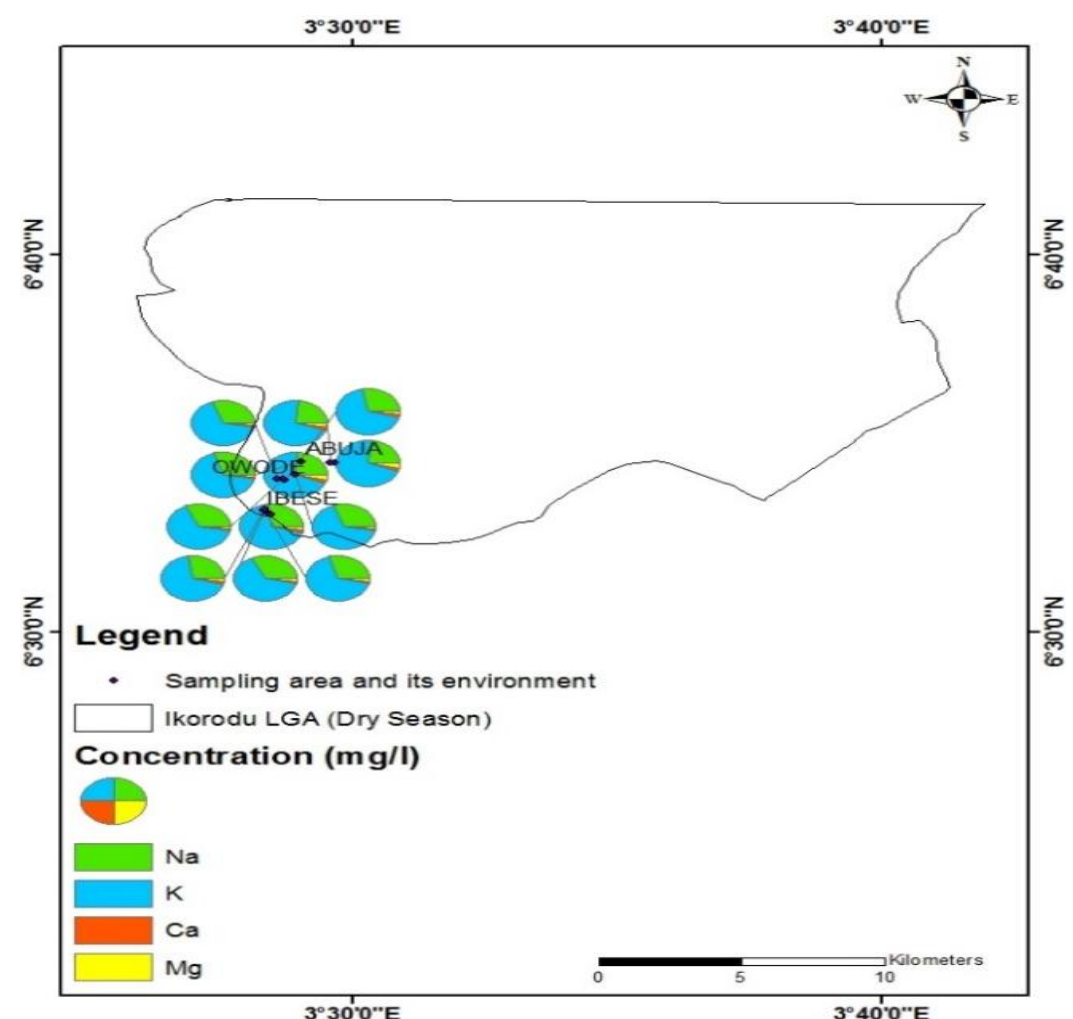

Figure-4a. Pie chart showing spatial distribution of cations in Ikorodu in the dry season. Source: Data Analysis (2015 -2017) using Arc GIS version 10.4.

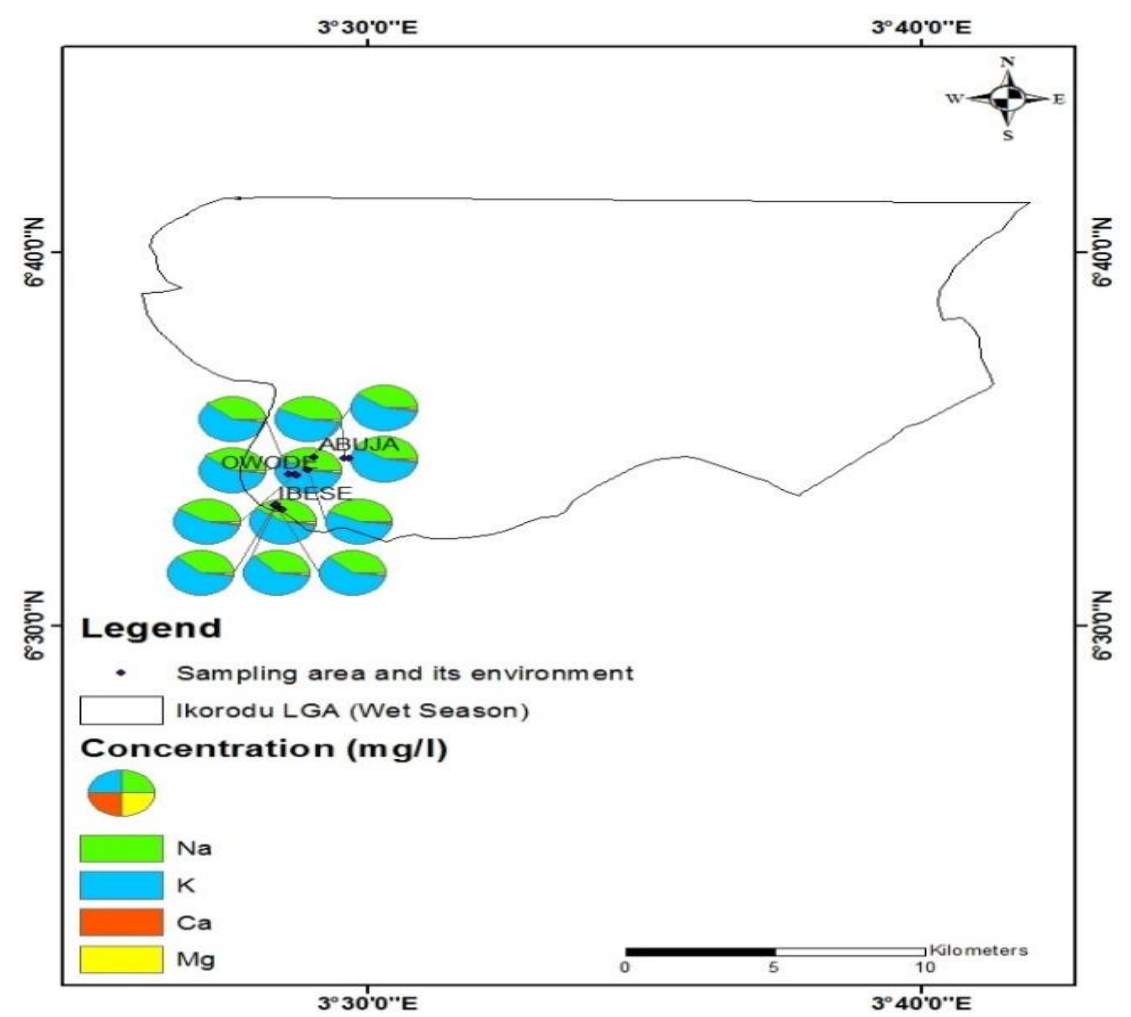

Figure-4b. Pie chart showing spatial distribution of cations in Ikorodu in the wet season Source: Data Analysis (2015 -2017) using Arc GIS version 10.4. 


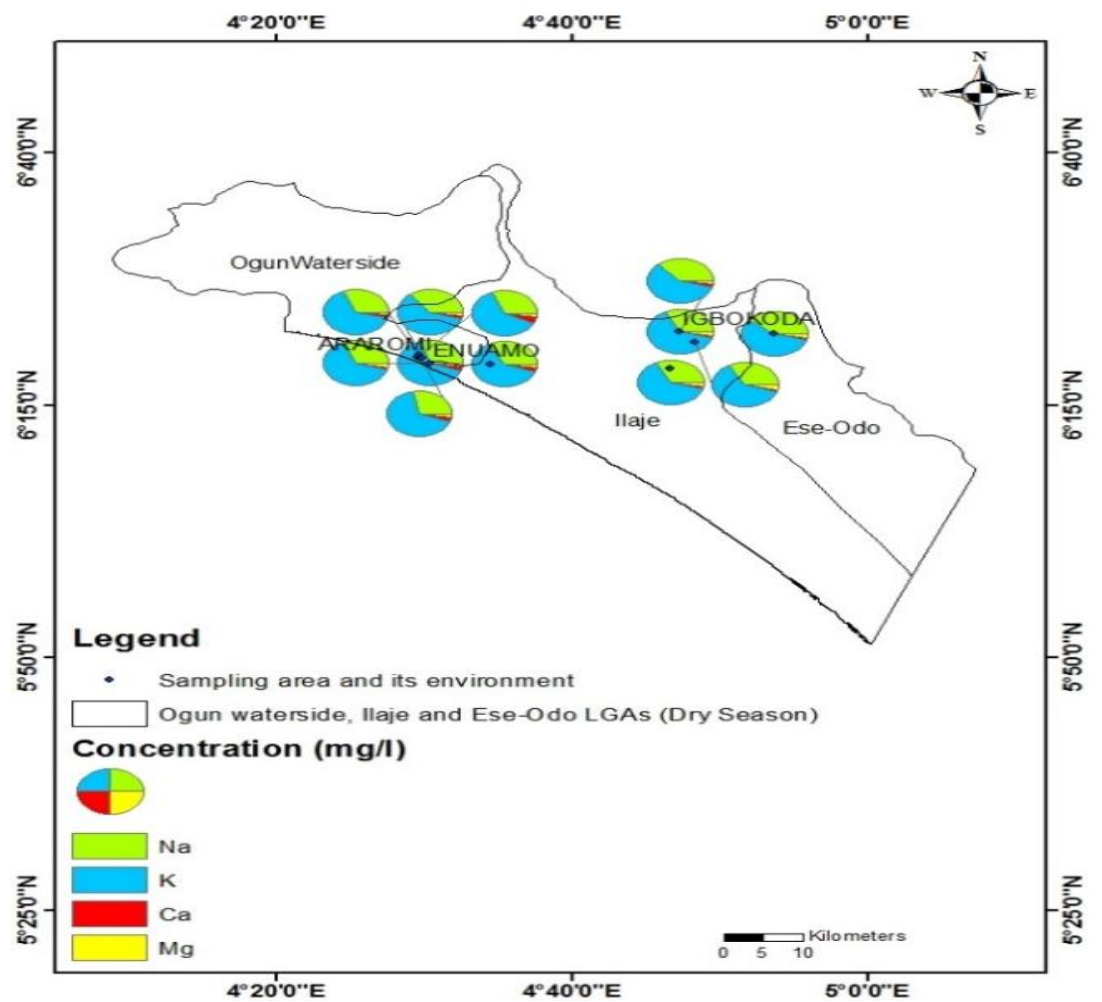

Figure-5a. Pie chart showing spatial distribution of cations in Ilaje/Ese-odo in the dry season. Source: Data Analysis (2015 - 2017) using Arc GIS version 10.4.

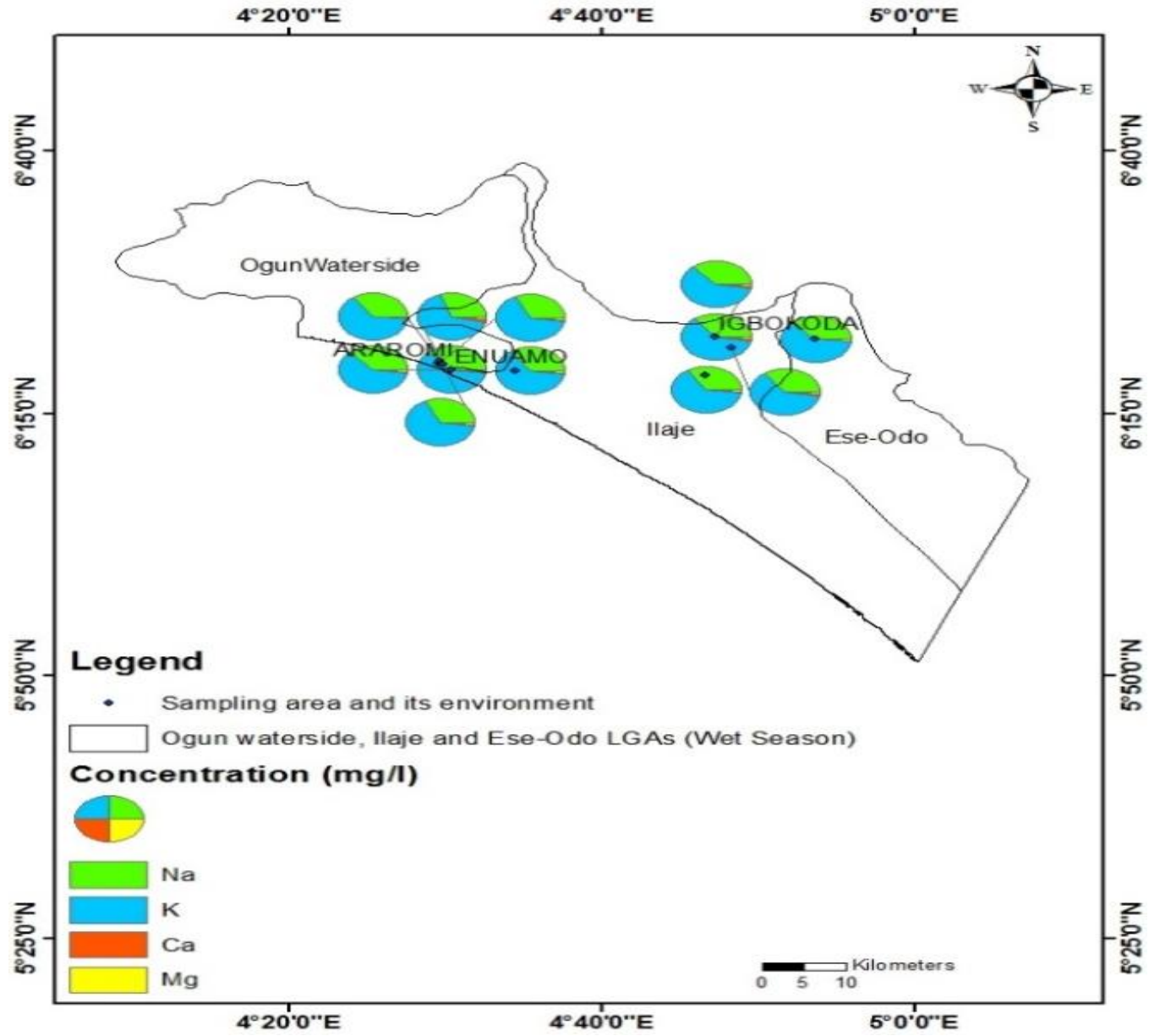

Figure-5b. Pie chart showing spatial distribution of groundwater cations in Ilaje/Ese-odo in the wet season. Source: Data Analysis (2015 -2017) using Arc GIS version 10.4. 


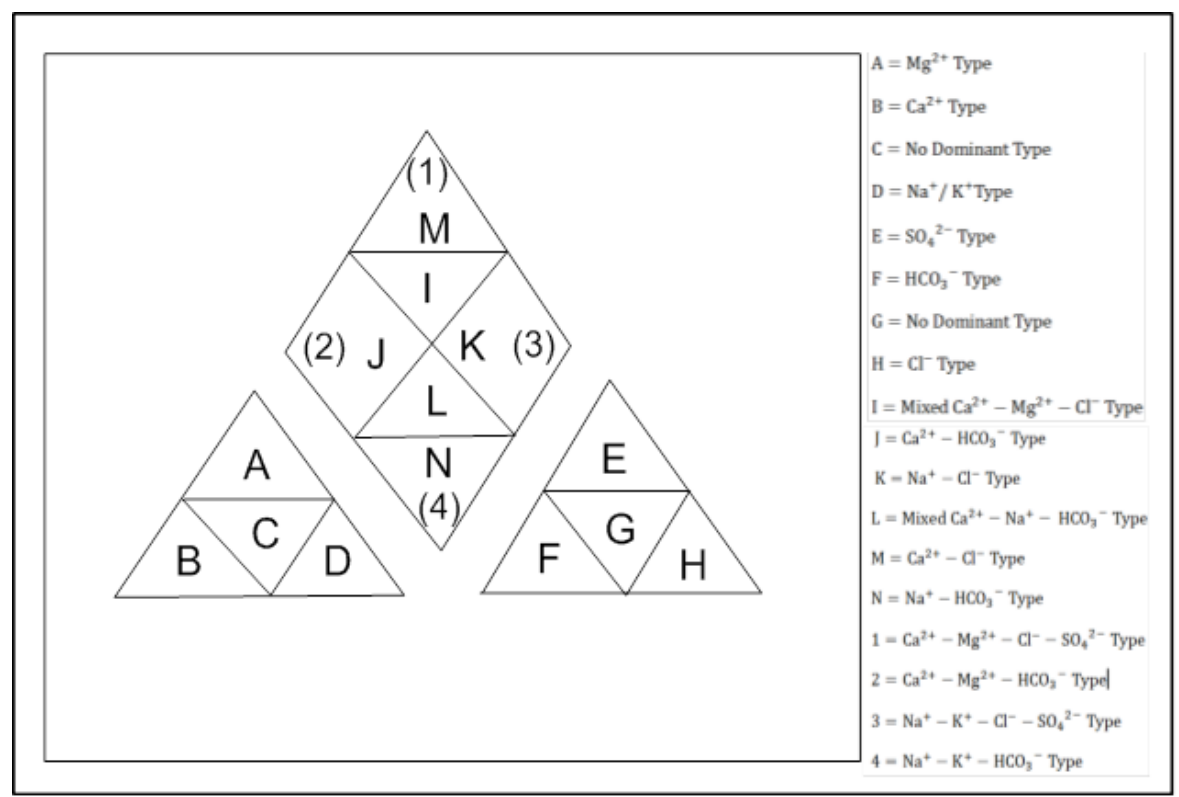

Source: Piper (1953).

Figure-6. A typical Piper trilinear chart.

\subsection{Hydro-chemical Facies of Groundwater in the Study Area}

The hydro-geochemistry of water samples was investigated using a concentration of main cations $\left(\mathrm{Ca}^{2+}, \mathrm{Mg}^{2+}\right.$, $\left.\mathrm{Na}^{+}, \mathrm{K}^{+}\right)$and anions $\left(\mathrm{HCO}_{3}{ }^{-}, \mathrm{SO}_{4}{ }^{2-}\right.$ and $\left.\mathrm{Cl}^{-}\right)$with the aid of Piper diagrams (Piper, 1953). The general sequences of ion concentrations in the region are in excess of $\mathrm{HCO}_{3}{ }^{-}>\mathrm{Cl}^{-}>\mathrm{SO}_{4}{ }^{2-}$ for anions and $\mathrm{K}^{+}>\mathrm{Na}^{+}>\mathrm{Ca}^{2+}>\mathrm{Mg}^{2+}$ for cations. A typical Piper trilinear chart shows the different water types, dominant cations and anions, and other ionic properties (Figure 6). The relative ionic characteristics of groundwater on a seasonal basis are illustrated with Piper trilinear diagrams (Figures 7-10). The Piper diagrams classify and compare water types in relation to the ionic components of various water samples (Hem, 1985). Piper's trilinear diagram revealed calcium $\left(\mathrm{Ca}^{2+}\right)$ and magnesium $\left(\mathrm{Mg}^{2+}\right)$ as the principal cations and sulphate and chloride as the main anions for two major water types $(\mathrm{Ca}-\mathrm{Cl}$ and $\mathrm{Ca}-\mathrm{Mg}-\mathrm{Cl}$ ) across the study location. The samples were associated with alkaline earth elements including calcium and magnesium, and strong acidic anions of sulphate and chloride. High levels of sulphate ions in groundwater suggest highly mineralized water. Groundwater $\mathrm{Ca}-\mathrm{Cl}$ and $\mathrm{Ca}-\mathrm{Mg}-\mathrm{Cl}$ showed that calcium in groundwater occurs as a result of water reaction with the soil, which increases $\mathrm{Ca}^{2+}$ and decreases $\mathrm{Na}^{+}$in relation to the inverse exchange process. In addition, saline water making contact with water previously under the influence of calcium carbonate may absorb $\mathrm{Ca}^{2+}$, leading to increased calcium in groundwater. Hounslow (1995) reported the calcium - magnesium water type and associated it with a shell deposit of fluvio-marine origin. The dominance of chloride ions in groundwater has been reportedly associated with seawater intrusion (Srinivas et al., 2017). This water type (Ca-Mg$\mathrm{Cl}$ ) indicated that alkaline earths exceed alkaline metals in these aquifers, strong acidic anions such as chloride predominate over weak acidic anions. Water of this type is characterized by permanent hardness and would not precipitate residual sodium carbonate when used for irrigation (Chadha, 1999). On the other hand, mixed $\mathrm{Ca}-\mathrm{Mg}-\mathrm{Cl}$ water in coastal environments indicates the mixing of high-salinity water with freshwater, normally arising from the surface, followed by ion exchange reaction processes.

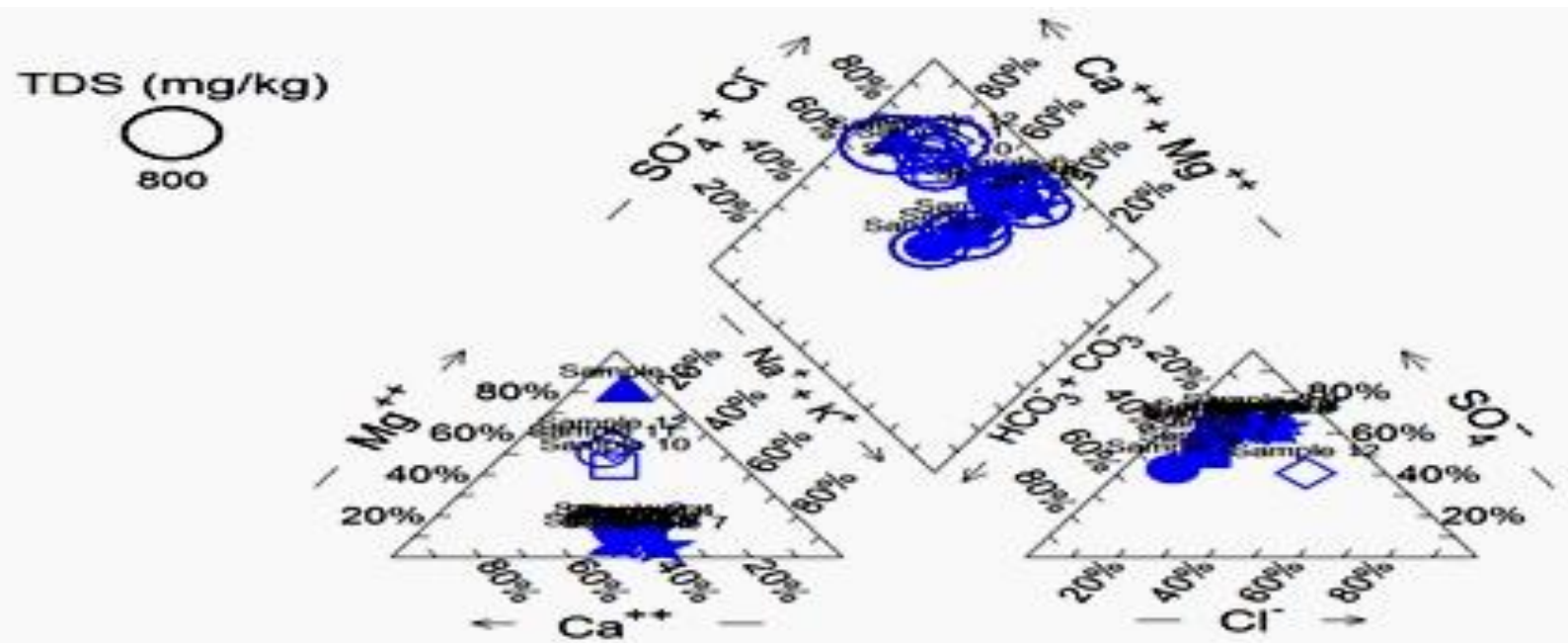

Figure-7. Piper trilinear diagram showing hydrochemical facies of groundwater in dry season I (December 2015-February 2016). Source: Data Analysis (2016). 
TDS ( $\mathbf{m g} / \mathbf{k g})$
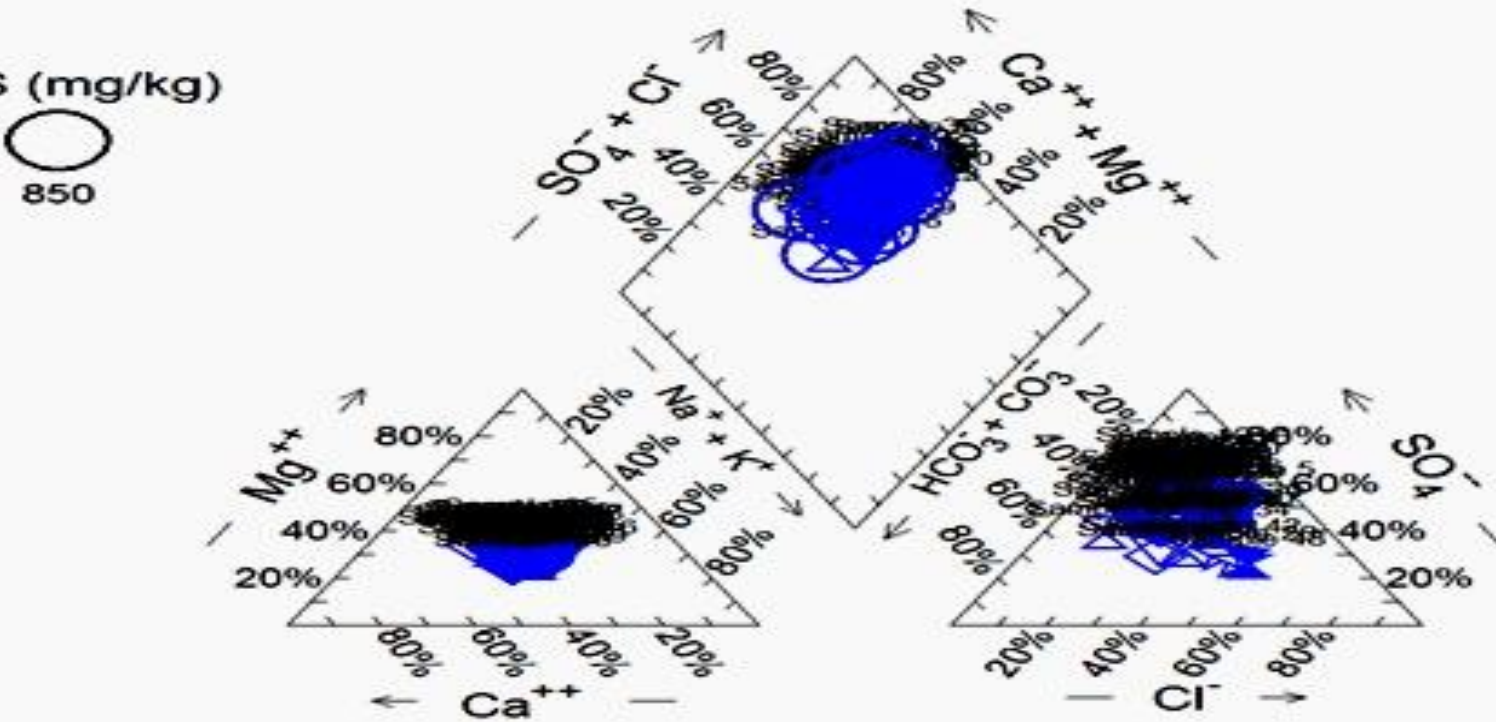

Figure-8. Piper trilinear diagram showing hydrochemical facies of groundwater in wet season I (August 2016-November 2016). Source: Data Analysis (2016).
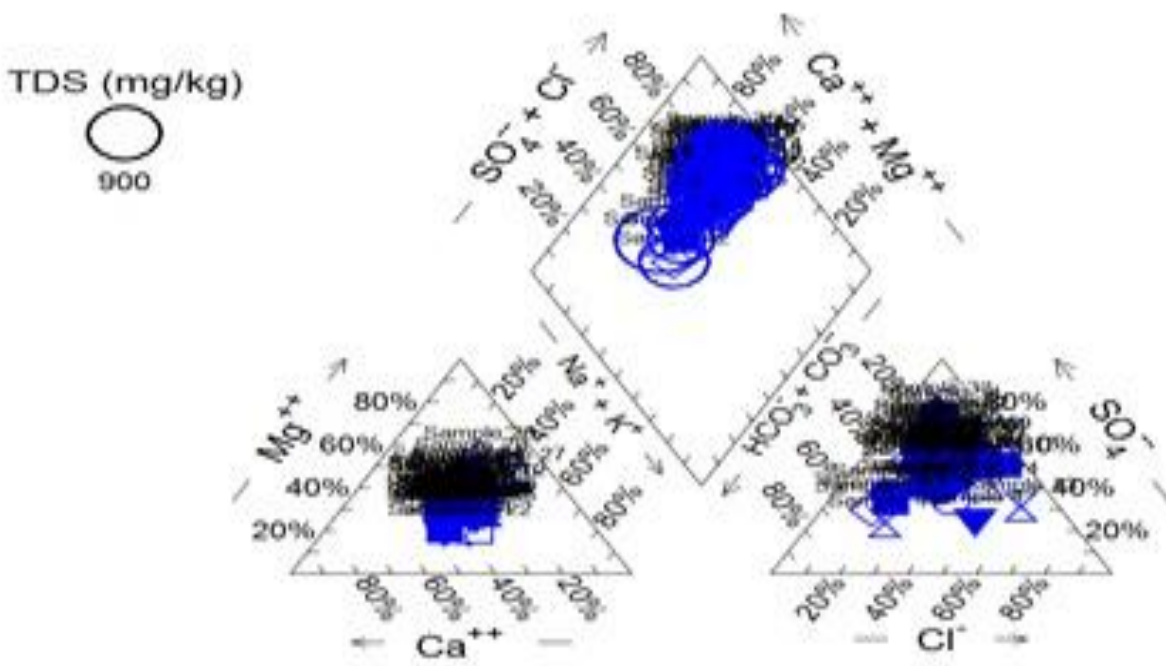

Figure-9. Piper trilinear diagram showing hydrochemical facies of groundwater in dry season II (December 2016-February 2017). Source: Data Analysis (2017)

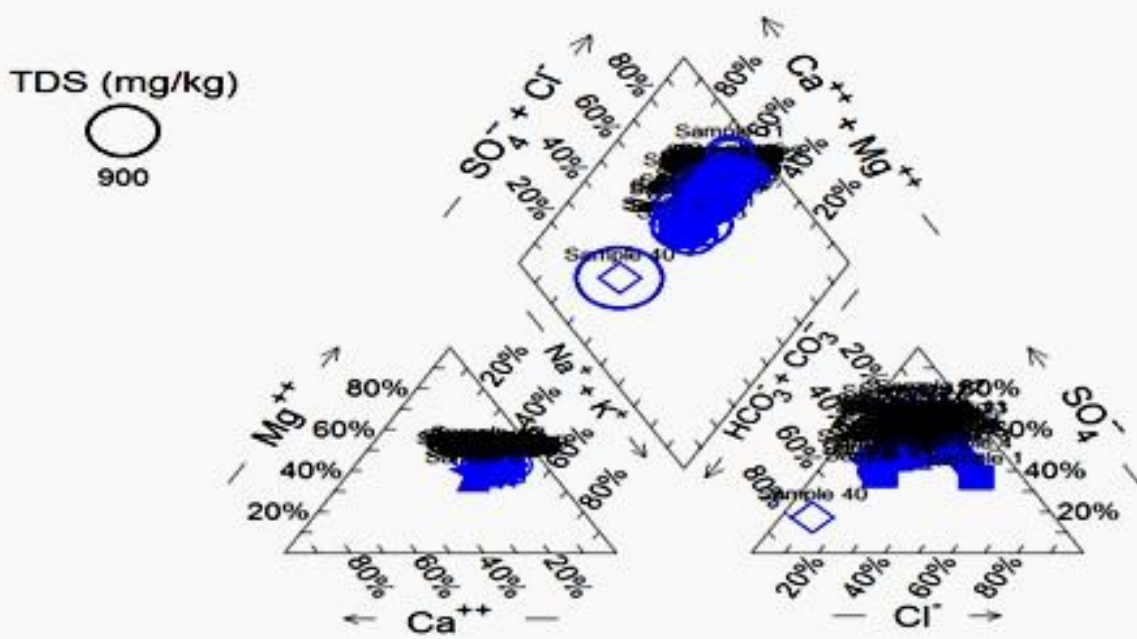

Figure-10. Piper trilinear diagram showing hydrochemical facies of groundwater in wet season II (August 2017-November 2017) Source: Data Analysis (2017). 


\subsection{Hydro-chemical Indices and Ionic Ratios}

The molar ionic ratio of $\mathrm{Mg} / \mathrm{Ca}$ was high, ranging from 0.05 to 13.46 . Higher values were obtained in the dry spell compared to the wet period. Elevated values $>5.0$ are an indicator of marine water influence on groundwater, unless otherwise influenced by processes such as cationic exchange intervention, across the study area. Low values indicate that the source of solutes in aquifers is the dissolution of soluble minerals (Batayneh \& Qassas, 2006). The $\mathrm{HCO}_{3} / \mathrm{Cl}$ ratio for groundwater ranged from 0.18 to 10.8 , falling outside the geochemical index of $0.1-5.0$, and this is attributed to the presence of inland waters (Custodio, 1987). The $\mathrm{Na} / \mathrm{Cl}$ ratios of saltwater intrusion are usually lower than those of marine water $(0.86$, molar ratio <0.86) while high values $(>1.0)$ classically characterize anthropogenic influence (Klassen, Allen, \& Kirste, 2014). Groundwater samples showed evidence of saline water intrusion, with ratios $<0.86$ while those $>1.0$ indicate contamination from saline and anthropogenic sources (Babu, Viswanadh, \& Rao, 2012). According to Klassen et al. (2014), the low Ca/ Mg ratio value as obtained in this study is indicative of saltwater contamination, since this is present in seawater at higher concentrations than calcium. The $\mathrm{Ca} / \mathrm{Mg}$ ratio indicates that $31 \%$ of groundwater samples have seawater intrusion, with ratios $<1.0$ during the dry season. Calcium-enriched groundwater has been reported as an indicator of saltwater intrusion (Carol, Kruse, \& MasPla, 2009). CEV values as expressed in Equation 1 showed the groundwater samples to be inland water, with values below the $1.2-1.3$ of seawater.

\subsection{Water Quality and Irrigation Application}

The quality of water for irrigation, according to Essington (2004), was evaluated in terms of ECiw expressed as deciSiemens per meter. ECiw values varied between 1.06 and $2.25 \mathrm{dS} / \mathrm{m}$. The maximum value was recorded in the Ilaje-Ese-odo area at the peak of the wet season. All values fall within 0.75-3.0 of medium salinity (increasing problem) for Badagry, Epe Ikorodu, and Ilaje/Ese-odo for both dry and wet seasons. Crop yields have been reported to generally decrease, according to Bresier, McNeal, and Carter (1982). Although certain plants may be tolerant at this range, the need for specific crop management adherence is advised when administering such groundwater for irrigation, to curtail potential soil deterioration and prevent poor crop growth.

The SAR calculated with Equation 2 is commonly applied because of its good correlation with exchangeable sodium percentage (ESP). SAR expresses the relative activity of sodium ions in the exchange process in terms of a ratio. SAR values according to Bouwer (1978) showed that about $75 \%$ of samples - mainly from Badagry, Epe, and Ilaje Ese-odo fall within the no-problem category (dry season). Moreover, $50 \%$ of samples, mainly from Ikorodu and Ilaje Ese-odo, fall within the increasing-problem category while $50 \%$ fall under the severe-problem category, which includes groundwater samples from Badagry and Epe during the wet spell. Low SAR values were obtained during the dry seasons compared to the wet seasons, indicating seasonal influence on the suitability of groundwater for irrigation. Since irrigation is commonly practiced in the absence of rain or when rainfall is inadequate, groundwater is therefore recommended for irrigation during the dry season, with close monitoring and assessment for optimum agricultural production while taking into consideration crop salt tolerance characteristics.

The percentage soluble sodium (PSS) calculated with Equation 4 revealed that 6.25 and $93.75 \%$ of samples denote doubtful and unsuitable, respectively, for irrigation (Wilcox, 1955). Groundwater application for optimum crop production based on SSP demands good agronomic practices with respect to soil and crop management.

Table-1. SAR of groundwater samples across locations (Bouwer, 1978).

\begin{tabular}{|c|c|c|c|}
\hline SAR & Classification & $\begin{array}{l}\text { Percentage falling } \\
\text { within this category }\end{array}$ & Description \\
\hline$<6$ & No problem & 43.75 & $\begin{array}{ll}\text { Suitable } & \text { for } \\
\text { irrigation } & \end{array}$ \\
\hline $6-9$ & $\begin{array}{l}\text { Increasing } \\
\text { problem }\end{array}$ & 31.25 & $\begin{array}{l}\text { Likely to cause soil } \\
\text { deterioration and } \\
\text { reduce yield }\end{array}$ \\
\hline$>9$ & $\begin{array}{l}\text { Severe } \\
\text { problem }\end{array}$ & 25 & $\begin{array}{l}\text { Unsuitable for } \\
\text { irrigation except } \\
\text { when otherwise } \\
\text { treated }\end{array}$ \\
\hline
\end{tabular}

The permeability index (PI) expressesd by Equation 3 and according to Doneen (1964) shows that all the groundwater was unsuitable for irrigation purposes, since values across all locations regardless of season were $>60$. Bouwer (1978) classified groundwater with SAR values $<6$ as "no problem", 6-9 as "increasing problem", and $>9$ as groundwater with "severe problems". SAR calculations (Table 1) showed that $43.75 \%$ of groundwater samples were under the "no problem", $31.25 \%$ "increasing problem", and $25 \%$ "severe problem". The result indicated that each location within the study area would require specific treatment with respect to water use, to prevent poor growth and crop performance.

\section{CONCLUSION}

The study clearly demonstrated the importance of physicochemical and ionic analysis of groundwater in selected coastal communities of Badagary, Epe, Ikorodu. and Ilaje/Ese-odo, south-western Nigeria in domestic and agriculture applications. Assessment of groundwater quality in the selected areas indicated that most of the 
parameters measured compare favorably with World Health Organization (WHO) (2011) for drinking water standards except for EC, alkalinity, and potassium the levels of which were above the permissible limits. Irrigation suitability of the water revealed that EC (salinity hazard), alkalinity, and potassium were at levels potentially detrimental to plant growth if applied without caution. Results further indicated the relative abundance of anions, $\mathrm{HCO}_{3}{ }^{-}>\mathrm{Cl}^{-}>\mathrm{SO}_{4}{ }^{2-}$ and cations, $\mathrm{K}^{+}>\mathrm{Na}^{+}>\mathrm{Ca}^{2+}>\mathrm{Mg}^{2+}$. Piper diagrams revealed magnesium and calcium as the principal cations and sulphate and chloride as the main anions relative percentage abundance. Groundwater described as $\mathrm{Mg}-\mathrm{Ca}$ and $\mathrm{Mg}-\mathrm{Ca}-\mathrm{Cl}$ was influenced by ionic exchange and saltwater intrusion. This water type $(\mathrm{Ca}-\mathrm{Mg}-\mathrm{Cl})$ indicated that alkaline earths exceed alkaline metals in these aquifers, and strong acidic anions such as chloride predominate over weak acidic anions. $\mathrm{CEV}$ and molar ratios of $\mathrm{Mg} / \mathrm{Ca}, \mathrm{HCO}_{3} / \mathrm{Cl}$, and $\mathrm{Na} / \mathrm{Cl}$ showed high values $(>1)$ across all locations. Molar ionic ratios indicated that the groundwater has a marine/saltwater signatory. The application of water for irrigation is linked to both season and location, as shown by irrigation indices indicating that each site requires specific water treatment to enhance optimum agricultural production without damaging the soil, and to prevent poor crop performance.

\section{Abbreviations}

CEV- Cation exchange capacity.

SAR - Sodium adsorption ratio.

PI- Permeability index.

PSS- Percentage soluble sodium.

LGA- Local government area.

IAR\&T- Institute of Agricultural Research and Training.

EC- Electrical conductivity.

ECiw- Electrical conductivity of water (deciSiemens).

$\mu \mathrm{S} / \mathrm{cm}$ - MicroSiemens per centimetre.

TDS- Total dissolved solids.

$\mathrm{Mg} / \mathrm{l}-$ Milligrams per liter.

WHO- World Health Organization.

SAI- Spectrum Analytic International.

$\mathrm{dS} / \mathrm{m}$ - DeciSiemens per meter.

ESP- Exchangeable sodium percentage.

Funding: The financial support provided by the Centre of Excellence for Agriculture and
Sustainable Environment, Federal University of Agriculture, Abeokuta (World Bank ACEO23)
is deeply appreciated in regard to the conduct of this research.
Competing Interests: The authors declare that they have no competing interests.
Acknowledgement: All authors contributed in an equal manner in designing the present
research.
Views and opinions expressed in this study are those of the authors views; the Asian Journal of
Agriculture and Rural Development shall not be responsible or answerable for any loss, damage,
or liability, etc. caused in relation to/arising out of the use of the content.

\section{REFERENCES}

Babu, M. M., Viswanadh, G., \& Rao, S. V. (2012). Assessment of saltwater intrusion along coastal areas of Nellore District, AP. International Journal of Scientific \& Engineering Research, 4(7), 173-178.

Batayneh, A. T., \& Qassas, H. A. (2006). Changes in quality of groundwater with seasonal fluctuations: An example from Ghor Sari area, southern Dead Sea coastal aquifers, Jordan. Journal of Environmental Sciences, 18(2), 263-269.

Bauder, T., Waskom, R., Sutherland, P., \& Davis, J. (2011). Irrigation water quality criteria. Colorado State University Extension Publication, Crop series/irrigation. Fact Sheet No. 0.506, 4.

Bouwer, H. (1978). Groundwater hydrology (International Student ed., pp. 410-420). Tokyo: McGraw-Hill Kogakusha Ltd.

Bresier, E., McNeal, B. L., \& Carter, D. L. (1982). Saline and sodic soils. New York: Springer - Verlag.

Carol, E., Kruse, E., \& Mas-Pla, J. (2009). Hydrochemical and isotopical evidence of ground water salinization processes on the coastal plain of Samborombón Bay, Argentina. Journal of Hydrology, 365(3-4), 335-345.

Chadha, D. (1999). A proposed new diagram for geochemical classification of natural waters and interpretation of chemical data. Hydrogeology Journal, 7(5), 431-439.

Custodio, E. (1987). Groundwater problems in coastal areas. In: Studies and Reports in Hydrology (UNESCO).

Doneen, L. D. (1964). Notes on water quality in agriculture published as a Water Science and Engineering Paper 4001. Department of Water Science And Engineering, University of California.

Essington, M. E. (2004). Soil and water chemistry, an integrative approach. USA: CRC Press.

Fatai, O. A., Egberongbe, P., Olusegun, C. N., \& Badejo, T. (2006). Oil spill disaster monitoring along Nigerian coastline, shaping the change, Munich, Germany (pp. 1-56). Building Nigeria's Response to Climate Change (BNRCC) Reports (2012). Towards a Lagos State Climate Change Adaptation Strategy.

Hakim, M., Juraimi, A., Begum, M., Hasanuzzaman, M., Uddin, M., \& Islam, M. (2009). Suitability evaluation of groundwater for irrigation, drinking and industrial purposes. American Journal of Environmental Sciences, 5(3), 413-419.

Hem, J. D. (1985). Study and interpretation of the chemical characteristics of natural water volume 2254. Department of the Interior, US Geological Survey.

Hopkin, B. G., Horneck, D. A., Stevens, R. G., Ellswort, J. W., \& Sullivan, D. M. (2007). Managing irrigation water for crop production in the Pacific Northwest (pp. 1-29). A Pacific North-western Extension Publication. 
Hounslow, A. W. (1995). Water - quality data analysis and interpretation. Boca Raton: Lewis Publishers.

Johnson, G., \& Zhang, H. (1990). Classification of irrigation water quality. Oklahoma cooperative Extension fact sheets. Retrieved from: http://www.osuextra.com.

Klassen, J., Allen, D. M., \& Kirste, D. (2014). Chemical indicators of saltwater intrusion for the Gulf Islands, British Columbia (pp. 1- 43). Department of Earth Sciences, Simon Fraser University, Final Report.

Kumar, K. S., Bharani, R., Magesh, N. S., Godson, P. S., \& Chandrasekar, N. (2014). Hydrogeochemistry and groundwater quality appraisal of part of south Chennai coastal aquifers, Tamil Nadu, India using WQI and fuzzy logic method. Applied Water Sciences, 4(4), 341-350.Available at: https://doi.org/10.1007/s13201-013-0148-4.

Luo, W., Gao, X., \& Zhang, X. (2018). Geo-chemical processes controlling the groundwater chemistry and fluoride contamination in the Yuncheng Basin, China—an area with complex hydro-geochemical conditions. PLoS One, 13(7), e0199082.Available at: https://doi.org/10.1371/journal.pone.0199082.

Manikandan, K., Natarajan, S., \& Sivasamy, R. (2011). Hydro-chemical grouping of ground water in coastal region of Cuddalore District, Tamil Nadu using cluster analysis. Research Journal of Environmental Sciences, 5(9), 763-771.Available at: $10.3923 /$ rjes.2011.763.771.

Mohan, R., Singh, A., Tripathi, J. K., \& Chowdhary, G. C. (2000). Hydrochemistry and quality assessment of groundwater in Naini industrial area, Allahabad district, Uttar Pradesh. Journal of the Geological Society of India, 55(1), 77-89.

Naseem, S., Hamza, S., \& Bashir, E. (2010). Groundwater geochemistry of Winder agricultural farms, Balochistan, Pakistan and assessment for irrigation water quality. European Water, 31, 21 -32.

Piper, A. (1953). A graphic representation in the geochemical interpretation of groundwater analyses. American Geophysical Union Transactions USA, 25(105), 914-923.

Raihan, F., \& Alam, J. B. (2008). Assessment of groundwater quality in sunamjang of Bangladesh. Iranian Journal of Environmental Health Science and Engineering, 5(3), $155-166$.

Raju, N. J., Shukla, U., \& Ram, P. (2011). Hydrogeochemistry for the assessment of groundwater quality in Varanasi: A fasturbanizing center in Uttar Pradesh, India. Environmental Monitoring and Assessment, 173(1), 279-300.

Sagnak, C. (2010). Groundwater pollution originated from geological formation, example of Konya-Cumra-Karapinar Plain with GIS application. Department of Geotechnical Services and Groundwater, State Hydraulics Works, Ankara, Turkey.

SAI (Spectrum Analytic Inc). (2010). Guide to interpreting irrigation water analysis, 1087 Jamison Road, Washington C. H. Ohio 43160. Retrieved from www.spectrumanalytic.com

Srinivas, Y., Aghil, T., Oliver, D. H., Nair, C. N., \& Chandrasekar, N. (2017). Hydrochemical characteristics and quality assessment of groundwater along the Manavalakurichi coast, Tamil Nadu, India. Applied Water Science, 7(3), 1429-1438.

Wilcox, L. (1955). Classification and use of irrigation waters (pp. 19). USDA circular 969.

World Health Organization (WHO). (2011). Guidelines for drinking water quality (4th ed.). Geneva: World Health Organization. 